
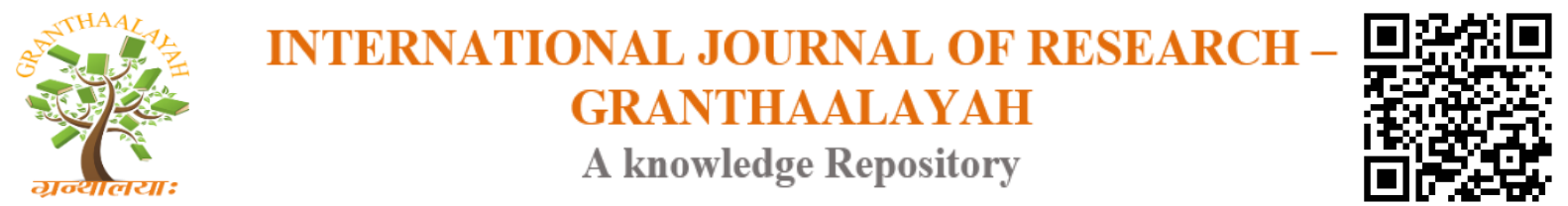

Science

\title{
RELATION OF FALOODA ICE CREAM LOVING WITH LEUKOCYTES IN URINE
}

\author{
Muhammad Imran Qadir ${ }^{1}$, Zubair Saleem *1 \\ ${ }^{1}$ Institute of Molecular Biology and Biotechnology, Bahauddin Zakariya University, Multan, \\ Pakistan
}

\begin{abstract}
Cells that protect us from infectious disease called white blood cell. There are five main types of leukocytes and they have short life cycle. Due to high range of white blood cells in urine mostly women have urinary infection. Large number of cells into urine give positive result normal range of them in urine 0 to 6 per high power field. One can reduce the urinary infection by adopting healthy life style. By eating falooda it is beneficial for our health but some time by eating too much it may cause cardiovascular disease and hyperglycemia.
\end{abstract}

Keywords: Multipotent Cell; Urinary Tract Infection; Pink Tinted Urine; Semiya And Basil Seeds.

Cite This Article: Muhammad Imran Qadir, and Zubair Saleem. (2019). "RELATION OF FALOODA ICE CREAM LOVING WITH LEUKOCYTES IN URINE." International Journal of Research - Granthaalayah, 7(5), 170-172. 10.29121/granthaalayah.v7.i5.2019.836.

\section{Introduction}

Leukocytes or white blood cells are cells that circulates in our blood and body fluids and protect us from infectious diseases or foreign substances. Basophils, eosinophils, neutrophils, lymphocytes and monocytes are main types of white blood cells. five main types. White blood cells have short life cycle, living from 10 days to 4 weeks and they derived and produced from multipotent cell. They play important role in blood clotting, engulf bacteria and produce antibodies. Leukocytes esterase is an enzyme found in leukocytes. A few bacteria cause the urinary tract infection which leads to white blood cells in urine. A normal range in blood is between 4, 600 to 10,000 white blood cells per microliter. While A normal range in urine is between 0 to 7 white blood cells per high power field. If number of white blood cells are high then test will be positive and person will have urinary tract infection. If person has pink tinted urine, burning sensation then there will be urinary tract infection. Women have high level of white blood cells in urine and tend to be greater risk for infections. There are many causes of white blood cells in urine such as kidney infection, bladder infection, and holding urine for too long is another cause of leukocytes elevated in urine. Pregnant women have high level of white blood cells in urine. Treatment of this disease 
is possible by taking antibiotics that treat urinary tract infections. One can reduces the risk of urinary tract infections by adopting proper personal hygiene, eating healthy diet and drinking 7 to 9 glasses of water daily. Patient suffering from this disease should visit doctor for checking levels of leukocytes in urine.

Mostly people like falooda ice cream during hot days because it is cool and sweet dish as well as drink. Falooda ice cream has cooling properties because presence of semiya and basil seeds that keep our body and brain cool and healthy. It is also beneficial for our health due to presence of large amount vitamins and mineral which present in diary product which is main ingredient of falooda ice cream. Falooda ice cream was fast eaten in Indian subcontinents it is also popular drink in different cities of Pakistan. Falooda ice cream is prepared or made in tall glass with many layers that give it beautiful shape. There are many flavours of ice cream like mango, pasta, kulfa and vanilla but the most favourite flavour that is eaten mostly among girls, boys and children due to good taste and fragrance of vanilla. One glass of falooda ice cream contains 220 calories which is sufficient to give instant energy to give the body and brain. People eat it because it is good source of glucose and vitamins that enhanced beauty of skin and give the strengthen to hair. But by eating too much ice cream it leads to different diseases like diabetes, cardiovascular disease and hyperglycemia due to presence of large amount of glucose or sugar which may be harmful for the normal function of kidneys that result leakage of different substances into urine like protein, glucose.

The objective of present study was to correlate the urine leukocytes with falooda ice cream.

\section{Materials and Methods}

First of all, the Materials that are required during urine test are gloves, container, dipstick strip, urine sample and labelling chart. Filled the empty container with the urine and dip the strip into urine sample for 5 to 6 second. After that dry the strip and matched it with labelling chart and note the value of luekocytes into urine.

\section{Project Design}

The main objective of this survey was to conducted the opinions of people about the loving of falooda ice cream. Almost there were 100 students in this survey who accomplished this survey in which $70 \%$ to $80 \%$ agreed that falooda ice cream is a good food as well as drink of summer and because its preparation is easy and not much expensive. But a few of subjects were who said this is a fatty food due to presence of dairy products and high amount of sugar or glucose and it can cause of heart disease.

\section{Results and Discussion}

Table 1: Relation of Falooda Ice Cream Loving with leukocytes in urine

\begin{tabular}{|l|l|l|l|l|}
\hline \multirow{2}{*}{ Falooda ice cream loving } & \multicolumn{2}{|l|}{ Males } & Females \\
\cline { 2 - 5 } & Negative value & Positive value & Negative values & Positive value \\
\hline Leukocytes in urine & $23 \%$ & $17 \%$ & $24 \%$ & $5 \%$ \\
\hline
\end{tabular}


This table shows that males that have negative values of white blood cells in their urine are $23 \%$ which are falooda ice cream loving and those males which have positive values are $17 \%$. similarly females with negative value are $24 \%$ and those females which have positive value are only $5 \%$. All these males and females are falooda ice cream loving. Falooda ice cream loving have cooling properties and give instance energy to the body.

Table 2: Relation of not falooda ice cream loving with leukocytes in urine

\begin{tabular}{|l|l|l|l|l|}
\hline \multirow{2}{*}{$\begin{array}{l}\text { Not loving falooda } \\
\text { ice cream }\end{array}$} & Males & Females \\
\cline { 2 - 5 } & Negative values & Positive Values & Negative Values & Positive Values \\
\hline Leukocytes in urine & $13 \%$ & $7 \%$ & $8 \%$ & $3 \%$ \\
\hline
\end{tabular}

This table reveals that males are $13 \%$ which have negative values of leukocytes while those which have positive value are $7 \%$. Similarly females with negative value are $8 \%$ and those female which have positive value are 3\%. All of these females and males are not falooda ice cream loving because they said, by eating too much falooda ice cream it can cause cardiovascular disease and obesity. Falooda ice cream contains too much sugar and glucose so it can increased the sugar level.

\section{Conclusion}

This was concluded that there is no relation between falooda ice cream loving and leukocytes in urine.

\section{References}

[1] Haynes, R. J., \& Williams, P. H. (1992). Changes in soil solution composition and pH. in urineaffected areas of pasture. Journal of soil Science, 43(2), 323-334.

[2] Applier, Robert A., et al. "Accuracy of urine specific gravity and osmolality as indicators of hydration status." International journal of sport nutrition and exercise metabolism 15.3 (2005): 236-251.

[3] Qadir MI, Javid A (2018) Awareness about Crohn's Disease in biotechnology students. Glo Adv Res J Med Medical Sci, 7(3): 062-064.

[4] Qadir MI, Saleem A (2018) Awareness about ischemic heart disease in university biotechnology students. Glo Adv Res J Med Medical Sci, 7(3): 059-061.

[5] Qadir MI, Ishfaq S (2018) Awareness about hypertension in biology students. Int J Mod Pharma Res, 7(2): 08-10.

[6] Qadir MI, Mehwish (2018) Awareness about psoriasis disease. Int J Mod Pharma Res, 7(2): 17-18.

[7] Qadir MI, Shahzad R (2018) Awareness about obesity in postgraduate students of biotechnology. Int J Mod Pharma Res, 7(2): 14-16.

[8] Qadir MI, Rizvi M (2018) Awareness about thalassemia in post graduate students. MOJ Lymphology \& Phlebology, 2(1): 14-16.

[9] Qadir MI, Ghalia BA (2018) Awareness survey about colorectal cancer in students of M. Phil Biotechnology at Bahauddin Zakariya University, Multan, Pakistan. Nov Appro in Can Study, 1(3): NACS.000514.2018.

[10] Qadir MI, Saba G (2018) Awareness about intestinal cancer in university student. Nov Appro in Can Study, 1(3): NACS.000515.2018.

*Corresponding author.

E-mail address: zubairsaleem038@ gmail.com 